\title{
Ownership structure and demand for independent directors: evidence from an emerging market
}

\author{
Quoc Trung Tran \\ Foreign Trade University, Ho Chi Minh City Campus, Ho Chi Minh City, Vietnam
}

\begin{abstract}
Purpose - In this study, we examine how ownership structure affects the use of independent directors in Vietnam - an emerging stock market.

Design/methodology/approach - We develop logit and tobit regression models to investigate the effects of ownership structure on the propensity to use independent directors and the number of independent directors on the board, respectively. Insider ownership and the use of independent directors are proposed to have a nonlinear relationship.

Findings - With a sample of 1,318 observations collected from 192 listed firms over the period from 2008 to 2017, we find that insider ownership and independent director appointment have a U-shaped relationship. It is positive when insiders hold a small proportion of shares, and turns out to be negative when insiders hold a large percentage of shares. In addition, both state ownership and foreign ownership are negatively related to firm decisions of appointing independent directors.

Practical implications - Our findings imply that minority shareholders should have appropriate actions to reduce agency costs and protect their own interests. In addition, policymakers should improve the effectiveness of corporate governance legislation to increase the presence of independent directors in order to protect minority shareholders. Moreover, government agencies also need to increase the number of independent directors in state-controlled firms as a means to improve their corporate governance. Foreign investors may be a substitute for independent directors; therefore, firms without independent directors are able to improve their corporate governance by attracting foreign investors.

Originality/value - While the extant literature shows that independent directors can help firms decrease agency costs of equity in financial decisions and performance, there are relatively few studies investigating corporate decisions to use independent directors. This paper contributes to the literature of corporate governance mechanisms through independent directors in emerging markets.
\end{abstract}

Keywords Ownership structure, Independent directors, Emerging market, Vietnam

Paper type Research paper

\section{Introduction}

According to Jensen and Meckling (1976), there is a separation of ownership and control in a corporation, and thus, the agency problem between shareholders and firm managers appears. Managers tend to use firm resources to increase their own benefits instead of maximizing shareholders' wealth. Therefore, independent directors are one of the most common approaches to monitor firm managers and mitigate minority shareholder expropriation in many countries. Independent directors are non-executive board members that have no business or personal connections with management. Prior studies mainly focus on the effects of independent directors on financial decisions (Sharma, 2011; Alves et al., 2015) and firm

(C) Quoc Trung Tran. Published in Journal of Economics and Development. Published by Emerald Publishing Limited. This article is published under the Creative Commons Attribution (CC BY 4.0) license. Anyone may reproduce, distribute, translate and create derivative works of this article (for both commercial and non-commercial purposes), subject to full attribution to the original publication and authors. The full terms of this license may be seen at http://creativecommons.org/licences/by/4.0/ legalcode

We are thankful to the Editorial Board and the anonymous reviewers for their valuable comments on earlier versions of this paper.
Ownership structure and independent directors

Received 10 March 2020 Revised 17 April 2020 Accepted 28 April 2020

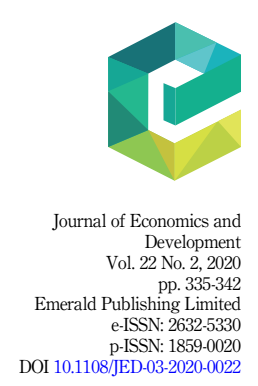


JED

22,2

336

performance (Armstrong et al., 2014; Cotter et al., 1997) and find that independent directors play an important role in reducing agency costs. However, there are relatively few studies analyzing corporate decisions to appoint independent directors. Peasnell et al. (2003) document a non-linear relationship between managerial ownership and the presence of outside directors. In this paper, we posit that the Vietnamese stock market is a good institutional environment to investigate how ownership structure (i.e. insider ownership, state ownership and foreign ownership) affects demand for independent directors. In this emerging market, legal regulations on independent directors fail to be enforceable, and appointing independent directors is mainly at firms' discretion.

We develop both logit and tobit regression models in which the relationship between insider ownership and decisions to use independent directors is non-linear. The effects of state ownership and foreign ownership and control variables (i.e. board size, market capitalization, firm profitability, firm leverage, CEO duality and legislation effects) are examined with a linear structure. Using a sample of 1,318 observations from 192 firms listed in Ho Chi Minh City Stock Exchange (HOSE) which accounts for about 90\% market capitalization of Vietnamese stock market, we find that the effect of insider ownership on independent director appointment is positive when insiders hold little stock; however, this effect turns to be negative when insiders have large stock. Both state ownership and foreign ownership negatively affect firm decisions to appoint an independent director.

The rest of this paper is structured as follows. Section 2 describes the institutional environment of the Vietnamese stock market, presents a literature review and proposes research hypotheses. Section 3 develops research models. Section 4 shows how to collect the research data and describes it. Section 5 presents results with both logit and tobit regression models. Section 6 presents the main conclusions.

\section{Institutional environment, literature review and hypothesis development}

The Vietnamese stock market was established with the first stock exchange located in Ho Chi Minh City in 2000, but it started to develop only five years later. Over the booming period from 2006 to 2008, the number of listed firms in Ho Chi Minh City Stock Exchange increased from about 30 to more than 200. At the end of 2018, it had 375 listed firms with a market capitalization of 2,900,000 million VND constituting approximately $90 \%$ in total market capitalization of the Vietnamese stock market. With a short period of rapid growth, the Vietnamese stock market witnessed a dramatic expansion, while legitimate regulations on corporate governance were not strong enough to monitor the stock market. Hai and Nunoi (2008) analyze Vietnam legislations on corporate governance and conclude that the country has a weak legal framework on corporate governance. Nguyen (2008) investigates corporate governance in Vietnam and finds that there is a big gap between legal regulations their implementation. Minh and Walker (2008) show that market transparency, investor protection and firm management are poor in the Vietnamese stock market. They measure the corporate governance score of selected Asian countries and show that Vietnam's score is only $50.9 \%$, lower than three southeast Asian countries, including Malaysia $(77.3 \%)$, Thailand $(72.7 \%)$ and Indonesia (60.0\%). Moreover, according to McGee (2009) weak corporate governance in Vietnam is due to the following reasons: (1) Laws and regulations have many conflicts and inconsistencies; (2) There are no sanctions for firms that fail to follow corporate governance rules and (3) Investment environment lacks information disclosure and transparency. In recent years, although Vietnamese Government has made many efforts to improve corporate governance, violations are still complicated. According to the Vietnam Association of Financial Executives (2017), over 83\% of listed firms have violations in information announcements. In addition, the Ministry of Finance issued Circular No. 121/2012/TT-BTC, which came into force in June 2012 to improve corporate governance. According to this legal 
document, independent directors shall account for at least one-third in listed firms' board of directors; however, most firms failed to appoint independent directors in 2012. Then, the Government continued to issue Decree No. 71/2017/ND-CP with the same requirement of board structure, but there were about $60 \%$ of listed firms without independent directors after the Decree came into force in 2017. The failure of this policy shows that the government fails to have an effective mechanism to control and impose appropriate sanctions on firms without independent directors, and the use of independent directors is determined mainly by firms.

The extant literature mainly focuses on the role of independent directors in corporate decisions and performance. Sharma (2011) examines the effects of board independence and independent directors' tenure on firms' dividend-paying propensity with a research sample of 944 US firms in 2006. They find that both board independence and tenure of independent directors are positively related to the likelihood to pay dividends. Besides, their additional analysis shows that equity incentive compensation for independent directors is the most prevalent determinant across alternative dividend measures. Alves et al. (2015) investigate the relationship between board composition and capital structure and find that firms with more independent directors have more external funds and more short-term debt compared with retained earnings. Furthermore, Cotter et al. (1997) show that independent directors enhance target shareholder benefits from tender offers during takeover attempts. With 1211 observations from 405 Chinese listed firms, Peng (2004) document a positive impact of independent directors on sales growth. Recently, Armstrong et al. (2014) show that independent directors can help firms improve corporate transparency.

Despite many prior studies on the effects of independent directors on corporate financial decisions and firm performance, there are few studies examining how firms appoint independent directors. Peasnell et al. (2003) conducted a pioneer study to investigate the relationship between managerial ownership and the use of outside directors. They find that this relationship is negative when managers hold a small proportion of shares; however, it is positive when managerial ownership is high. These findings imply that the former is determined by the incentive-alignment demand, and the latter is determined by the entrenchment-amelioration demand shareholders. In Vietnam, the use of independent directors is an agreement between shareholders and insiders since the legislation on corporate governance is insufficiently effective. We argue that shareholders create more pressure on insiders that hold little stock to appoint independent directors, and there is a positive relationship between insider ownership and the use of independent directors. Nevertheless, this pressure is low when insiders own more stock, and there is a negative relationship between insider ownership and independent director appointment.

H1. Insider ownership is positively related to the use of independent directors if insiders hold little stock, and this relationship is negative if insiders hold large stock.

In addition, government agencies are large shareholders in many listed firms, which are originally $100 \%$ state-owned before going public. These state-related firms are commonly politically connected and they do not prefer independent directors who may make government agencies difficult to control firm resources. Therefore, state ownership is likely to negatively affect the use of independent directors.

H2. State ownership is negatively related to the use of independent directors.

Besides, prior studies conducted in Vietnam document that foreign ownership helps firms reduce information asymmetry and agency costs of shareholders (Vo, 2018). We argue that foreign investors are a monitoring channel to reduce agency costs. Therefore, firms with higher foreign investors are less likely to appoint independent directors.

H3. Foreign ownership is negatively related to the use of independent directors.
Ownership structure and independent directors

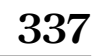


JED

22,2

338

\section{Research models}

While Peasnell et al. (2003) measure the use of independent directors only by the number of independent directors on the board and use pooled OLS regression, this paper uses different regression models based on a new argument on the presence of independent directors on the board. We argue that the use of independent directors is a two-step process with two decisions as follows: (1) Whether the firm should have independent directors and (2) How many independent directors the firm should have. Therefore, we develop two separate research models to examine the effects of ownership structure on these two decisions. First, we use the logit regression model to models to investigate the relationship between ownership structure on the propensity to use independent directors since the dependent variable is binary (to use or not to use independent directors). Second, we use the tobit regression model to estimate how ownership structure influences the number of independent directors $\mathrm{n}$ the board. From the econometric perspective, the number of independent directors is left-censored since it is continuous to the right of zero. Pooled OLS regression for the full sample of all firms or the sub-sample of firms with independent directors is biased due to the selection problem. Thus, tobit should be used instead (Wooldridge, 2010). However, to ensure that our research results are robust, we also present pooled OLS regression results in Section 4.

Consistent with Peasnell et al. (2003), insider ownership and the use of independent directors are proposed to have a non-linear relationship. The equations for logit and tobit models are as follows.

$$
\begin{aligned}
P \_ \text {Independent }= & \alpha+\beta_{1} \mathrm{Own} \_ \text {insider }+\beta_{1} \mathrm{Own} \_ \text {insider }{ }^{2}+\beta_{3} \mathrm{Own} \_ \text {state } \\
& +\beta_{4} \mathrm{Own} \_ \text {foreign }+\beta_{5} \text { Board_size }+\beta_{6} \mathrm{Mar} \_ \text {cap }+\beta_{7} \mathrm{ROA} \\
& +\beta_{8} \text { Leverage }+\beta_{9} \text { Duality }+\beta_{10} \mathrm{Y} 2013+\gamma \text { Industry dummies }+\varepsilon
\end{aligned}
$$

$$
\begin{aligned}
N \_ \text {Independent }= & \alpha+\beta_{1} \text { Own_insider }+\beta_{1} \text { Own_insider }{ }^{2}+\beta_{3} \text { Own_state } \\
& +\beta_{4} \text { Own_foreign }+\beta_{5} \text { Board_size }+\beta_{6} \text { Mar_cap }+\beta_{7} \text { ROA } \\
& +\beta_{8} \text { Leverage }+\beta_{9} \text { Duality }+\beta_{10} \mathrm{Y} 2013+\gamma \text { Industrydummies }+\varepsilon
\end{aligned}
$$

where $P_{-}$Independent is the propensity to appoint independent directors. $N \_$Independent is the number of independent directors on the board. Own_insider is insider ownership. Own_state is state ownership. Own_foreign is foreign ownership. Board_size is board size. Mar_cap is market capitalization. ROA is firm profitability. Leverage is firm leverage. Duality is CEO duality. Y2013 is a dummy variable to control the effect of Circular No. 121/ 2012/TT-BTC. Definitions of key research variables are presented in Table 1.

\section{Research data}

To construct the research data, we select firms listed in Ho Chi Minh City Stock Exchange the main stock exchange of Vietnam. Financial information, ownership structure and director's information are provided by Stoxplus. After eliminating firms in financial sector and observations with missing information, we obtain a full sample of 1,318 firm-years from 192 listed firms over the period from 2008 to 2017. Table 2 describes the research sample. The annual number of firms increases significantly over the research period from 57 firms (2008) to 188 firms (2017). In addition, Panel B shows that Industrials constitutes the largest percentage of observations in the research data with $36.6 \%$, followed by Consumer goods 


\begin{tabular}{|c|c|c|c|}
\hline Variables & Variable names & Definitions & Ownership \\
\hline$P \_$Independent & $\begin{array}{l}\text { Propensity to appoint } \\
\text { independent directors }\end{array}$ & $\begin{array}{l}\text { A dummy variable assigned } 1 \text { if observations have at least } \\
\text { one independent director and } 0 \text { otherwise }\end{array}$ & indeper \\
\hline$N \_$Independent & $\begin{array}{l}\text { Number of independent } \\
\text { directors }\end{array}$ & Number of independent directors on the board & \\
\hline Own_insider & Insider ownership & Total proportion of shares held by insiders & \\
\hline Own_state & State ownership & Percentage of shares held by state agencies & 339 \\
\hline Own_foreign & Foreign ownership & Percentage of shares held by foreign investors & \\
\hline Board_size & Board size & Total number of directors on the board & \\
\hline Mar_cap & Market capitalization & Natural logarithm of market capitalization & \\
\hline $\mathrm{ROA}$ & Firm profitability & Net income divided by total assets & \\
\hline Leverage & Firm leverage & Total liabilities divided by total assets & \\
\hline Duality & CEO duality & $\begin{array}{l}\text { A dummy variable assigned } 1 \text { if } \mathrm{CEO} \text { simultaneously takes } \\
\text { the chairman position }\end{array}$ & \\
\hline Y2013 & $\begin{array}{l}\text { Effect of Circular No. 121/ } \\
\text { 2012/TT-BTC }\end{array}$ & $\begin{array}{l}\text { A dummy variable assigned } 1 \text { if observations fall in the } \\
\text { year } 2013\end{array}$ & $\begin{array}{l}\text { Definitions of key } \\
\text { research variables }\end{array}$ \\
\hline
\end{tabular}

\begin{tabular}{|c|c|c|c|c|c|c|}
\hline Year & $N$ & Year & $N$ & Year & $N$ & \\
\hline \multicolumn{7}{|c|}{ A. Annual number of firms } \\
\hline 2008 & 57 & 2012 & 140 & 2016 & 171 & \\
\hline 2009 & 79 & 2013 & 141 & 2017 & 188 & \\
\hline 2010 & 112 & 2014 & 146 & & & \\
\hline 2011 & 124 & 2015 & 160 & & & \\
\hline Industry & $N$ & $\%$ & Industry & $N$ & $\%$ & \\
\hline \multicolumn{7}{|c|}{ B. Industry distribution } \\
\hline Oil \& Gas & 11 & 0.8 & Health care & 58 & 4.4 & \\
\hline Basic materials & 207 & 15.7 & Consumer services & 82 & 6.2 & \\
\hline Industrials & 482 & 36.6 & Utilities & 117 & 8.9 & \\
\hline \multirow[t]{2}{*}{ Consumer goods } & 331 & 25.1 & Technology & 30 & 2.3 & \\
\hline & Mean & Median & S.D. & Min & $\operatorname{Max}$ & \\
\hline \multicolumn{7}{|c|}{ C. Descriptive statistics } \\
\hline$P$ Independent & 0.39 & 0.00 & 0.49 & 0.00 & 1.00 & \\
\hline$N \_$Independent & 0.79 & 0.00 & 1.20 & 0.00 & 5.00 & \\
\hline Own_insider & 0.10 & 0.12 & 0.16 & 0.00 & 0.64 & \\
\hline Own_state & 0.22 & 0.07 & 0.25 & 0.00 & 0.75 & \\
\hline Own_foreign & 0.13 & 0.12 & 0.15 & 0.00 & 0.65 & \\
\hline Board_size & 5.78 & 5.00 & 1.37 & 3.00 & 11.00 & \\
\hline Mar cap & 26.89 & 26.70 & 1.40 & 24.75 & 30.28 & \\
\hline $\mathrm{ROA}^{-}$ & 0.07 & 0.06 & 0.06 & -0.04 & 0.24 & \multirow{3}{*}{$\begin{array}{r}\text { Table } 2 . \\
\text { Research data } \\
\text { description }\end{array}$} \\
\hline Leverage & 0.48 & 0.50 & 0.21 & 0.07 & 0.83 & \\
\hline Duality & 0.04 & 0.04 & 0.19 & 0.00 & 1.00 & \\
\hline
\end{tabular}

(25.1\%) and Basic materials (15.7\%) while Oil \& Gas accounts for the smallest proportion with only $0.8 \%$.

$P \_$Independent is the propensity to appoint independent directors. $N \_$Independent is the number of independent directors. Own_insider is insider ownership measured by the total proportion of shares held by insiders. Own_state is state ownership measured by the total 
JED

22,2

340

percentage of shares held by government agencies. Own_foreign is foreign ownership measured by the total proportion of shares held by foreign investors. Board_size is the number of directors on the board. Mar_cap is market capitalization. ROA is firm profitability measured by return on assets. Leverage is firm leverage measured by total liabilities divided by total assets. Duality is CEO duality, which takes 1 if CEO is simultaneously the chairman and 0 otherwise.

Furthermore, Panel $\mathrm{C}$ reports descriptive statistics of key research variables. All financial variables are winsorized at 3\% to eliminate the outlier effects. Firms with independent directors constitute $39 \%$ of the research sample. The number of independent directors ranges from 0 to 5 , and its mean is 0.79 . On average, insiders hold about $10 \%$ of shares, government agencies own $22 \%$, and foreign investors account for $13 \%$. The number of directors on the board varies from 3 to 11, and its median value is 5 .

\section{Results and discussion}

Table 3 presents estimation results for both logit and tobit models to investigate the effects of ownership structure on the propensity to use independent directors and the number of independent directors on the board, respectively. In addition, the result of pooled OLS regression is also reported as a robustness check. We find that the coefficients of insider ownership and its quadratic values are positive and negative, respectively. These findings imply that there is a U-shaped relationship between insider ownership and the use of independent directors. When insiders have a small proportion of shares, this relationship is positive; however, it turns to be negative when insiders hold a large percentage of shares. Although these results are opposite to Peasnell et al. (2003), they indicate that appointing independent directors reflects the conflict of interest between shareholders and insiders when legislations in corporate governance are less effective in an emerging market. When insiders hold a small number of stocks, shareholders are more powerful to force them to appoint independent directors. However, when insiders have more stocks, this pressure is limited, and higher insider ownership leads to a lower propensity to appoint independent directors. These understandings imply that firm-level corporate governance through independent directors in Vietnamese stock markets significantly relies on the balance of power between shareholders and insiders.

\begin{tabular}{|c|c|c|c|}
\hline Variables & Logit model & Tobit model & Pooled OLS \\
\hline Own_insider & $4.895 * * *(4.05)$ & $5.764^{* * *}(3.77)$ & $2.075^{* * *}(3.25)$ \\
\hline Own insider $^{2}$ & $-8.238 * * * *(-3.86)$ & $-9.458 * * * *(-3.51)$ & $-3.244 * * *(-2.90)$ \\
\hline Own_state & $-0.660 * *(-2.24)$ & $-0.956 * *(-2.53)$ & $-0.437 * * *(-2.87)$ \\
\hline Own_foreign & $-1.585 * * *(-3.30)$ & $-2.099 * * *(-3.36)$ & $-0.810 * * *(-3.16)$ \\
\hline Board̄_size & $0.076(1.60)$ & $0.219 * * *(3.67)$ & $0.133^{* * * *}(5.23)$ \\
\hline Mar_cap & $0.066(1.23)$ & $0.009(0.13)$ & $-0.031(-1.08)$ \\
\hline $\mathrm{ROA}$ & $0.573(0.49)$ & $0.427(0.29)$ & $0.491(0.79)$ \\
\hline Leverage & $-0.822 * *(-2.42)$ & $-1.438 * * * *(-3.29)$ & $-0.506^{* * *}(-2.87)$ \\
\hline Duality & $-0.389(-1.22)$ & $-0.407(-1.01)$ & $-0.143(-0.88)$ \\
\hline Y2013 & $0.132(0.69)$ & $0.216(0.90)$ & $0.092(0.91)$ \\
\hline Intercept & $-1.803(-1.27)$ & $-0.732(-0.41)$ & $1.248 *(1.66)$ \\
\hline \multicolumn{4}{|l|}{ Industry dummies } \\
\hline$R$-squared & & & 0.12 \\
\hline$F$-statistics & & & $10.25^{* * * *}$ \\
\hline Chi-squared & $113.99 * * *$ & $152.26^{* * * *}$ & \\
\hline Number of observations & 1,318 & 1,318 & 1,318 \\
\hline
\end{tabular}

Regression results

Note(s): $*$ is significant at $10 \%, * *$ is significant at $5 \%, * * *$ is significant at $1 \%$ 
The dependent variable of the logit model is the propensity to appoint independent directors ( $P$ _Independent). The dependent variable for the tobit model and pooled OLS is the number of independent directors ( $N$ Independent). Own_insider is insider ownership measured by the total proportion of shares held by insiders. Own_state is state ownership measured by the total percentage of shares held by government agencies. Own_foreign is foreign ownership measured by the total proportion of shares held by foreign investors. Board_size is the number of directors on the board. Mar_cap is market capitalization. ROA is firm profitability measured by return on assets. Leverage is firm leverage measured by the total liabilities divided by total assets. Duality is CEO duality, which takes 1 if CEO is simultaneously the chairman and 0 otherwise. Y2013 is a dummy variable to control the effect of Circular No. 121/ 2012/TT-BTC.

Moreover, Table 3 also illustrates that state and foreign ownership are negatively related to the use of independent directors. These results indicate that firms with higher state ownership are more controlled by government agencies, and they tend to have a lower propensity to use independent directors that may restrict government agencies' control. Besides, firms with higher foreign ownership experience better monitoring service from foreign investors; thus, they are less likely to appoint independent directors. This finding indicates that foreign investors may be a substitute for independent directors in firm-level corporate governance mechanisms.

\section{Conclusions}

While the extant literature shows that independent directors can help firms decrease agency costs of equity in financial decisions and performance, there are relatively few studies investigating corporate decisions to use independent directors. In this study, we examine how ownership structure affects the use of independent directors in the Vietnamese stock market. With a sample of 1,318 observations collected from 192 listed firms over the period from 2008 to 2017, we find that insider ownership and independent director appointment have a U-shaped relationship. It is positive when insiders hold a small proportion of shares, and turns out to be negative when insiders hold a large percentage of shares. In addition, both state ownership and foreign ownership are negatively related to firm decisions of appointing independent directors. These understandings imply that minority shareholders should have appropriate actions to reduce agency costs and protect their own interests. In addition, policymakers should improve the effectiveness of corporate governance legislation to increase the presence of independent directors in order to protect minority shareholders. Moreover, government agencies also need to increase the number of independent directors in state-controlled firms as a means to improve their corporate governance. Foreign investors may be a substitute for independent directors; therefore, firms without independent directors are able to improve their corporate governance by attracting foreign investors. Future studies may extend this line of research by investigating the presence of independent directors on the board from the supply side.

\section{References}

Alves, P., Couto, E.B. and Francisco, P.M. (2015), "Board of directors' composition and capital structure", Research in International Business and Finance, Vol. 35, pp. 1-32.

Armstrong, C.S., Core, J.E. and Guay, W.R. (2014), "Do independent directors cause improvements in firm transparency?", Journal of Financial Economics, Vol. 113 No. 3, pp. 383-403.

Cotter, J.F., Shivdasani, A. and Zenner, M. (1997), "Do independent directors enhance target shareholder wealth during tender offers?", Journal of Financial Economics, Vol. 43 No. 2, pp. 195-218. 
JED

22,2

\section{2}

Hai, B.X. and Nunoi, C. (2008), "Corporate governance in Vietnam: a system in transition", Hitotsubashi Journal of Commerce and Management, Vol. 42 No. 1, pp. 45-65.

Jensen, M.C. and Meckling, W.H. (1976), "Theory of the firm: managerial behavior, agency costs and ownership structure", Journal of Financial Economics, Vol. 3 No. 4, pp. 305-360.

McGee, R.W. (2009), "An overview of corporate governance practices in Vietnam", in McGee, R.W. McGee (Ed.), Corporate Governance in Developing Economies: Country Studies of Africa, Asia and Latin America, Springer US, Boston, MA.

Minh, T.L. and Walker, G. (2008), "Corporate governance of listed companies in Vietnam”, Bond Law Review, Vol. 20 No. 2, Article. 6.

Nguyen, D. (2008), Corporate Governance in Vietnam: Regulations, Practices and Problems, Central Institute for Economic Management, Hanoi, Vietnam, pp. 1-69.

Peasnell, K.V., Pope, P.F. and Young, S. (2003), "Managerial equity ownership and the demand for outside directors", European Financial Management, Vol. 9 No. 2, pp. 231-250.

Peng, M.W. (2004), "Outside directors and firm performance during institutional transitions", Strategic Management Journal, Vol. 25 No. 5, pp. 453-471.

Sharma, V. (2011), "Independent directors and the propensity to pay dividends", Journal of Corporate Finance, Vol. 17 No. 4, pp. 1001-1015.

Vo, X.V. (2018), "Foreign ownership and corporate cash holdings in emerging markets", International Review of Finance, Vol. 18 No. 2, pp. 297-303.

Wooldridge, J.M. (2010), Econometric Analysis of Cross Section and Panel Data, MIT Press, 10th, Cambridge.

\section{Corresponding author}

Quoc Trung Tran can be contacted at: tranquoctrung.cs2@ftu.edu.vn

For instructions on how to order reprints of this article, please visit our website:

www.emeraldgrouppublishing.com/licensing/reprints.htm

Or contact us for further details: permissions@emeraldinsight.com 